\title{
PENGARUH IKLAN TERHADAP SIKAP KONSUMEN YAMAHA DI PERGURUAN TINGGI SWASTA ISLAM KOTA MEDAN
}

\author{
Nadia Ika Purnama \\ FakultasEkonomi dan Bisnis Universitas Muhammadiyah Sumatera Utara \\ email : nadiaika@umsu.ac.id
}

\begin{abstract}
ABSTRAK
Persaingan bisnis yang semakin ketat menuntut setiap perusahaan untuk selalu bersaing dalam menarik konsumen.Para pengusaha sebagai produsen harus saling berlomba- lomba untuk mencari faktor-faktor yang mempengaruhi sikap konsumen dalam memilih suatu produk dan menyusun strategi pemasaran yang tepat sehingga dapat mendominasi pasar yang ada.Salah satu tahap dari pemasaran adalah periklanan, yaitu merupakan tahapan yang sangat penting karena tanpa adanya periklanan berbagai produk dan jasa tidak akan dapat berjalan dengan lancar. Semakin berkembangnya teknologi dan semakin ketatnya persaingan, kebutuhan akan sebuah produk yang mampu mendukung mobilitas kerja sangat dicari oleh masyarakat banyak termasuk sepeda motor. Sepeda motor saat ini menjadi kebutuhan bagi masyarakat dalam menjalankan aktifitas keseharian, ditengah timbulnya kemacetan disana-sini dan tingginya tingkat mobilitas kota medan saat ini.

Tujuan penelitian ini adalah untuk mengetahui iklan berpengaruh terhadap sikap konsumen Yamaha di Perguruan Tinggi Swasta Islam Kota Medan.Peneliti menggunakan instrumen penelitianmerupakan data yang didapat dan hasil kuesioner yang diisi oleh mahasiswa perguruan tinggi swasta islam dikota medan. Dalam penelitian ini jumlah sampel yang digunakan berjumlah 150 orang. Hasil pengolahan data dimanaiklan berpengaruh terhadap sikap konsumen Yamaha di Perguruan Tinggi Swasta Islam Kota Medan
\end{abstract}

Kata Kunci :Iklan, Sikap Konsumen

\begin{abstract}
Business competition that is increasingly stringent requires every company to always compete in attracting consumers. Entrepreneurs as producers must compete with each other to find factors that influence consumers' attitudes in choosing a product and formulate the right marketing strategy so that it can dominate the existing market. One stage of marketing is advertising, which is a very important stage because without advertising a variety of products and services will not run smoothly. As technology develops and competition is getting tighter, the need for a product that is able to support work mobility is highly sought after by many people including motorbikes. Motorbikes are currently a necessity for people in carrying out daily activities, amid the emergence of congestion here and there and the high level of mobility of today's terrain.

The purpose of this study was to determine the effect of advertising on consumer attitudes of Yamaha at the Medan Islamic Private Higher Education. Researchers using research instruments are the data obtained and the results of questionnaires filled by students of Islamic private universities in the city of the field. In this study the number of samples used was 150 people. Data processing results where advertisements affect the consumer attitudes of Yamaha at the Medan Islamic Private Higher
\end{abstract}

Keywords: Advertising, Consumer Attitudes 


\section{PENDAHULUAN}

Persaingan bisnis yang semakin ketat menuntut setiap perusahaan untuk selalu bersaing dalam menarik konsumen.Para pengusaha sebagai produsen harus saling berlomba- lomba untuk mencari faktor-faktor yang mempengaruhi sikap konsumen dalam memilih suatu produk dan menyusun strategi pemasaran yang tepat sehingga dapat mendominasi pasar yang ada.Semakin berkembangnya teknologi dan semakin ketatnya persaingan, kebutuhan akan sebuah produk yang mampu mendukung mobilitas kerja sangat dicari oleh masyarakat banyak termasuk sepeda motor. Sepeda motor saat ini menjadi kebutuhan bagi masyarakat dalam menjalankan aktifitas keseharian, ditengah timbulnya kemacetan disana-sini dan tingginya tingkat mobilitas kota medan saat ini.Salah satu tahap dari pemasaran adalah periklanan, yaitu merupakan tahapan yang sangat penting karena tanpa adanya periklanan berbagai produk dan jasa tidak akan dapat berjalan dengan lancar. Dewasa ini jumlah media massa sudah semakin banyak sehingga diperlukan suatu pengetahuan yang memadai bagi pemasar dan perencana media agar dapat menyampaikan pesan pemasarannya secara efektif dan efisien. Periklanan sering kali menjadi kegiatan menghambur-hamburkan uang karena tidak bisa menghasilkan penjualan produk yang memadai.Pemasaran seringkali tidak memahami bagaimana memadukan berbagi instrument promosi yang tersedia secara baik agar menghasilkan efek maksimal bagi penjualan produk perusahaan. Pemasar dan perencanaan media seringkali tidak paham media apa yang cocok untuk mempromosikan produknya karna jumlah media yang sudah banyak. Mereka tidak mengetahuisecara baik program apa yang seharusnya dipilih atau tidak mengetahui berapa kali suatu iklan ditayangkan atau menentukan kreatifitas suatu iklan.

Banyak

perusahaan

memperkenalkan produk barunya melalui iklan yang dibuat semenarik mungkin dengan tujuan untuk menarik para konsumen dan mengajak konsumen untuk membeli produk tersebut.Iklan dapat dibagi menjadi 2 yaitu iklan dalam media elektronik maupun media cetak. Seperti yang kita ketahui iklan dalam media elektronik yaitu iklan yang melalui media radio dan media televisi sedangkan dalam iklan media cetak yaitu iklan yang mnelalui Koran, majalah, spanduk dalain-lain. Iklan televisi mempunyai peran penting dalam mempromosikan sebuah produk agar tema yang ingin disampaikan, maka dibuatlah iklan yang sangat menarik, dengan kata-kata yang mudah diingat, juga dengan endorser (artis pendukung) iklan tersebut ditayangkan ditelevisi agar membuat konsumen terpengaruh untuk menggunakan produk tersebut. Sukses tidaknya sebuah iklan yang ditayangkan dalam televise sangat mempengaruhi sikap konsumen untuk membeli produk yang ditawarkan.

Menurut Kotler (2007) pemasaran adalah suatu fungsi organisasi dan seperangkat proses untuk menciptakan, mengkomunikasikan, dan menyerahkan nilai kepada pelanggan dan mengelola hubungan pelanggan dengan cara yang menguntungkan organisasi dan para pemilik sahamnya.Menurut Mahfumud Machfoedz (2010), bauran pemasaran adalah sarana pemasaran taktis meliputi produk, harga, tempat, dan promosi yang dibaurkan untuk mendaat respon yang diinginkan dari pasar sasaran.

Iklan adalah salah satu dari promotion mix, Kotler dan Amstrong (2012) mengatakan bahwa promotion mix is the specific blend of promotion tools that the company uses to persuasively communicate customer value and buid customer relationship. Maksudnya, bauran promosi adalah sekelompok alat-alat yang digunakan oleh perusahaan untuk mengkomunikasikan nilai pelanggan secara persuasif dan membangun hubungan pelanggan.Kotler dan Keller (2012) mengatakan "advertising can be a cost-effective way to disseminate messages, ehether to buid a brand preference or to educate people. Maksudnya iklan dapat menjadi cara yang efektif untuk menyebarkan pesan, baik untuk menbangun preferensi merek atau untuk mendidik masyarakat.Tujuan dari sebuah iklan adalah kegiatan untuk mengkomunikasikan secara spesifik yang harus diselesaikan dengan target pelanggan selama jangka waktu tertentu.Dalam periklanan dikenal istilah iklan lini atas (above the line) dan iklan lini bawah (low the line) dengan definisi sebagai 
berikut, (Rangkuti, 2009): (1). Iklan lini atas (above the line), (2).Iklan lini bawah (low the line).Periklanan dapat disajikan dalam bentuk dan media sebagai berikut: (1). Media Cetak yaitu surat kabar, majalah, brosur, leaflet, direct email, (2)Media elektronikadalah media yang paling efektif dan banyak digunakan oleh perusahaan karena media ini dapat menjangkau semua lapisan masyarakat. Media elektronik terdiri atas media audio dan audio visual, (3).Media outdoor (luar ruangan) yaitu billboard, signboard, umbul-umbul, sticker.

Menurut Mowen (2002) tahap pemproresan informasi konsumen adalah proses dimana konsumen di ekspose untuk menerima informasi, menjadi terlibat dengan informasi tersebut, memperhatikan informasi,memahami informasi, mengingatnya, dan mencari kembali untuk digunakan dimasa mendatang. Dalam pemrosesan informasi ini adal 5 tahap yang dilalui, yaitu: (1). Exposure, (2). Perhatian (attention), (3). Pemahaman (comprehension), (4). Penerimaan (acceptance), (5). Penyimpanan (retention)

Sikap adalah suatu kecendrungan yang dipelajari untuk bereaksi terhadap penawaran produk dalam masalah-masalah yang baik ataupun yang kurang baik secara konsekuen (Dharmmesta Dan Handoko, 2012), setiap unsur dalam definisi ini sangat penting untuk memahami mengapa dan bagaimana sikap terkait dalam prilaku konsumen dan pemasaran. Secara umum, fumgsi sikap dibagi menjadi 4 golongan (psychologymania,2012) yaitu: (1). Sikap sebagai alat untuk menyesuaikan diri, (2). Sikap sebagai alat pengatur tingkah laku, (3). Sikap sebagai alaat pengatur, (4). Sikap sebagai pernyataan kepribadian, (5). Hubungan sikap konsumen dengan keputusan pembelian

Menurut wahyuni (2008) sikap adalah pernyataan-pernyataan atau penilaian evaliatif berkaitan dengan objek, orang, atau suatu peristiwa. Sedangkan menurut simamora (2002) bahwa sikap terdapat 3 komponen yaitu: (1). Congnitive component, (2). Affective component, (3). Behavioral component

Adapun kerangka hipotesis dalam penelitian ini adalah

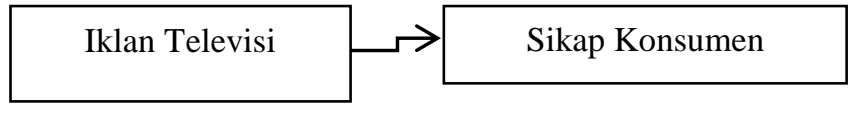

\section{Gambar 1. Kerangka Konseptual}

Berdasarkan permasalahan di atas, hipotesisnya adalah iklan berpengaruh terhadap sikap konsumen Yamaha di Perguruan Tinggi Swasta Islam Kota Medan

\section{METODOLOGI PENELITIAN}

A. Jenis penelitian dan Sumber Data

Penelitian ini menggunakan analisis kuantitatif.Data dalam penelitian ini menggunakan data primer dan data sekunder.Data primer atau data empiris yang diperoleh dari penyebaran koesioner.Kuesioner adalah alat pengumpul data berupa daftar pertanyaan tertulis untuk memperoleh keterangan dari sejumlah responden, pengukuran menggunakan Skala Likert.Sedangkan data skunder adalah data yang diperoleh oleh peneliti melalui bukubuku yang berkaitan dengan penelitian ini, literature dan artikel.

\section{B. Teknik Analisis Data}

\section{Regresi linier Berganda}

Analisis regresi bertujuan untuk memgetahui seberapa besar pengaruh variabel iklan televisi (X1) terhadap sikap konsumen (Y), maka pengolahan data akan dilakukan dengan menggunakan SPSS Versi 20.0.Pengujian asumsi klasik terlebih dahulu dilakukan sebelum melakukan pengujian hipotesis agar model regresi dapat menghasilkan penduga yang tidak bias. Uji asumsi klasik ini terdiri dari :

\section{Uji Normalitas}

Tujuan dari uji normalitas adalahuntuk menguji apakah dalam model regresi, variabel pengganggu atau residual memiliki distribusi normal (Ghozali, 2013). Uji normalitas dalam penelitian ini dilakukan dengan menggunakan uji Kolmogorov-Smirnov, dengan melihat tingkat signifikansi 5\%. Dasar pengambilan keputusan dari uji normalitas adalah dengan melihat probabilitas asymp.sig (2-tailed) > 0,05 maka data berdistribusi normal dan sebaliknya jika asymp.sig (2-tailed) $<0,05$ maka data berdistribusi tidak normal. 


\section{Multikolinearitas}

Uji multikolinearitas bertujuan untuk menguji apakah dalam model regresi ditemukan adanya korelasi (hubungan) antar variabel independen (Ghozali, 2006).Model regresi yang baik seharusnya tidak terjadi korelasi di antara variabel independen (tidak terjadi multikolinieritas). Untuk mengidentifikasi ada atau tidaknya multikolinearitas dalam penelitian ini, dapat dilihat dari besarnya nilai tolerance dan variance inflation factor (VIF). Batas nilai tolerance dengan ketentuan sebagai berikut : 1. Jika nilai tolerance $<0,10$ dan VIF $>10$, maka terdapat korelasi diantara salah satu variabel independen dengan variabel-variabel independen lainnya atau terjadi multikolinearitas.

2. Jika nilai tolerance $>0,10$ dan $\mathrm{VIF}<10$, maka tidak terjadi korelasi diantara salah satu variabel independen dengan variabel-variabel independen lainnya atau tidak terjadi multikolinearitas.

3. Uji multikoliniearitas juga dapat dilihat dari nilai korelasi antar variabel independen. Jika nilai korelasi antar variabel independen di bawah 95\%, maka dapat disimpulkan tidak terjadi multikolinieritas.

\section{Heteroskedastisitas}

Uji heteroskedastisitas bertujuan untuk menguji apakah dalam model regresi terjadi ketidaksamaan variance dari residual satu pengamatan ke pengamatan yang lain(Ghozali, 2006). Jika variancedari residual satu pengamatan kepengamatan lain tetap, maka disebut homoskedastisitas dan jika berbeda disebut heterokedastisitas. Model regresi yang baik adalah yang Homokedastisitas atau tidak terjadi Heterokedastisitas.Uji heteroskedastisitas dapat dilihat dengan uji Glejser. Uji Glejser meregresikan nilai absolut residual terhadap variabel independen (Ghozali, 2006). Jika setiap variabel independen nilai signifikannya lebih besar dari $\alpha_{0,05}$, maka dapat disimpulkan tidak terjadi heteroskedastisitas

Uji t

Uji parsial digunakan untuk menguji apakah variabel bebas (X) secara individu mempunyai hubungan dengan variabel $(\mathrm{Y})$. Untuk menguji signifikan hubungan digunakan rumus uji statistik t.

Dengan ketentuan :

$$
\begin{aligned}
\mathrm{H}_{0} \quad: \mathrm{r}_{\mathrm{s}}=\quad & 0, \text { artinya tidak terdapat } \\
& \text { hubungan signifikan } \\
& \text { antara variabel bebas }(\mathrm{X}) \\
& \text { dengan variabel terikat }(\mathrm{Y})
\end{aligned}
$$

$\mathrm{H}_{\mathrm{a}}: \mathrm{r}_{\mathrm{s}} \neq 0$, artinya terdapat hubungan signifikan antara variabel bebas $(\mathrm{X})$ dengan variabel terikat $(\mathrm{Y})$

Kriteria pengujian :

$\mathrm{H}_{0}$ diterima apabila $-\mathrm{t}_{\text {tabel }} \leq \mathrm{t}_{\text {hitung }} \leq \mathrm{t}_{\text {tabel }}$ pada $\alpha=5 \%$, df $=\mathrm{n}-\mathrm{k}$

$\mathrm{H}_{\mathrm{a}}$ ditolak apabila $\mathrm{t}_{\text {hitung }}>\mathrm{t}_{\text {tabel }}$ atau $t_{\text {hitung }}<-t_{\text {tabel }}$

Uji F

Uji F digunakan untuk menguji signifikansi koefiensi korelasi ganda deangan Ketentuan pengujian :

$\mathrm{H} 0$ = Tidak ada pengaruh iklan televisi terhadap sikap konsumen.

$\mathrm{Ha}=$ Ada pengaruh iklan televisi terhadap sikap konsumen.

Ketentuan pengujian :

a. Tidak signifikan jika $\mathrm{H}_{0}$ diterima dan $\mathrm{H}_{\mathrm{a}}$ bila $\mathrm{F}_{\text {hitung }}<\mathrm{F}_{\text {tabel }}$ dan $-\mathrm{F}_{\text {hitung }}>$ $\mathrm{F}_{\text {tabel }}$

b. Signifikan jika $\mathrm{H}_{0}$ ditolak dan $\mathrm{H}_{\mathrm{a}}$ diterima bila $\mathrm{F}_{\text {hitung }}>\mathrm{F}_{\text {tabel }}$ dan $\mathrm{F}_{\text {hitung }}<-\mathrm{F}_{\text {tabel }}$

\section{Koefisien Determinasi}

Perhitungan nilai koefisien determinasi $\left(R^{2}\right)$ digunakan untuk mengukur kedekatan hubungan dari model yang dipakai.Koefisien determinasi $\left(R^{2}\right)$ yaitu angka yang menunjukan besarnya kemampuan varians atau penyebaran dari independen variable (variable bebas) yang menerangkan dependen variable (variabel terikat) atau angka yang menunjukan seberapa besar independen variable (variabel bebas) dapat menjelaskan dependen variable (variabel terikat).

Besarnya nilai koefisien determinasi adalah antara 0 hingga $1\left(0 \leq R^{2}\right.$ $\leq 1)$, dimana jika nilai koefisien mendekati 1, maka model tersebut dikatakan baik karena semakin dapat menjelaskan hubungan antara variabel bebas dengan variabel terikat.

\section{HASIL DAN PEMBAHASAN}

Penelitian ini menguji Analisis Pengaruh Iklan Sepeda Motor Yamaha Melalui Televisi Dan Atribut Terhadap 
Sikap Konsumen di Perguruan Tinggi Swasta Islam kota Medan). Variabel independen yang digunakan adalah strategi iklan dan atribut.Data yang digunakan dalam penelitian ini adalah data primer yang merupakan data yang didapat dan hasil kuesioner yang diisi oleh mahasiswa perguruan tinggi swasta islam dikota medan. Dalam penelitian ini jumlah sampel yang digunakan berjumlah 150 orang.

\section{A. Deskripsi Data Identitas Responden 1. Jenis Kelamin}

Dari jumlah 150 yang diteliti banyaknya responden yang diteliti sebanyak 93 laki-laki dan 57 orang perempuan seperti yang terlihat dalam tabel dibawah ini.

Tabel 1 Persentase Jenis Kelamin Responden

\begin{tabular}{llcc}
\hline No & $\begin{array}{c}\text { Jenis } \\
\text { Kelamin }\end{array}$ & Jumlah & Persen \\
\hline 1 & Laki-laki & 93 & $62 \%$ \\
\hline 2 & Perempuan & 57 & $38 \%$ \\
\hline & Jumlah & 150 & $100 \%$ \\
\hline
\end{tabular}

Pada tabel 1 dapat dideskripsikan bahwa yang memakai produk sepeda motor yamaha lebih diminati oleh laki-laki yaitu sebanyak 93 orang atau sebesar $62 \%$.

\section{Usia}

Usia yang dijadikan sampel dalam penelitian ini antara 17-20 tahun,sampai 20 tahun keatas, untuk mengetahui tingkat persentasenya dapat dilihat pada tabel bawah ini:

Tabel 2 Usia Responden

\begin{tabular}{cccc}
\hline No & Usia & Jumlah & Persen \\
\hline 1 & $17-20$ tahun & 87 & $58 \%$ \\
\hline
\end{tabular}

\begin{tabular}{lccc}
\hline 2 & $\begin{array}{c}20 \text { tahun ke } \\
\text { atas }\end{array}$ & 63 & $42 \%$ \\
\hline Jumlah & 150 & $100 \%$ \\
\hline
\end{tabular}

Pada tabel 2 menunjukan bahwa untuk usia responden, frekuensi mayoritas responden adalah yang berusia 17-20 tahun sebesar 58\%. Hal ini menunjukkan bahwa yang menggunakan produk sepeda motor Yamaha banyak yang berusia 17-20 tahun.

\section{Tingkat Pendidikan Responden}

Tingkat pendidikan responden yang dijadikan sampel pada penelitian ini diketahui mulai dari SMA, SMK, dan MA seperti dapat dilihat pada tabel dibawah ini:

\section{Tabel 3Tingkat Pendidikan Responden}

\begin{tabular}{cccc}
\hline No & Keterangan & Jumlah & Persen \\
\hline 1 & SMA & 45 & $30 \%$ \\
\hline 2 & SMK & 72 & $48 \%$ \\
\hline 3 & MA & 33 & $22 \%$ \\
\hline & Jumlah & 150 & $100 \%$ \\
\hline
\end{tabular}

Pada tabel 3 menunjukkan bahwa untuk tingkat pendidikan responden, frekuesi mayoritas adalah responden yang berpendidikan SMK sebesar 48\%.Hal ini menunjukkan bahwa yang menggunakan produk sepeda motor Yamaha banyak digunakan oleh tingkat mahasiswa yang memiliki tamatan SMK.

\section{B. Hasil Uji Validitas Dan Reabilitas 1. Validitas}

Dari hasil pengujian SPSS yang dilakukan dapat dilihatvaliditas kuesioner yang digunakan. Kriteria pengujian validitas dilihat dari hasil yang didapat dari pengujian validitas dengan membandingkan nilai sig. 2tailed $<0,05=$ valid. Berikut kesimpulan validitas kuesioner penelitian.

Tabel 4Hasil Pengujian Validitas Variabel Iklan $\left(\mathbf{X}_{1}\right)$

\begin{tabular}{llll} 
Pernyataan & Nilai korelasi & Probabilitas & Kesimpulan \\
\hline
\end{tabular}




\begin{tabular}{cccc}
\hline Pernyataan 1 & 0,770 & $0,000<0,05$ & Valid \\
\hline Pernyataan 2 & 0,784 & $0,000<0,05$ & Valid \\
\hline Pernyataan 3 & 0,784 & $0,000<0,05$ & Valid \\
\hline Pernyataan 4 & 0,784 & $0,000<0,05$ & Valid \\
\hline Pernyataan 5 & 0,610 & $0,000<0,05$ & Valid \\
\hline Pernyataan 6 & 0,610 & $0,000<0,05$ & Valid \\
\hline Pernyataan 7 & 0,762 & $0,000<0,05$ & Valid \\
\hline Pernyataan 8 & 0,762 & $0,000<0,05$ & Valid \\
\hline Pernyataan 9 & 0,610 & $0,000<0,05$ & Valid \\
\hline Pernyataan 10 & 0,762 & $0,000<0,05$ & Valid \\
\hline
\end{tabular}

Sumber : Hasil SPSS 20.0 (2017)

Tabel 5Hasil Pengujian Validitas Variabel Sikap Konsumen (Y)

\begin{tabular}{cccc}
\hline Pernyataan & Nilai korelasi & Probabilitas & Kesimpulan \\
\hline Pernyataan 1 & 0,586 & $0,000<0,05$ & Valid \\
\hline Pernyataan 2 & 0,498 & $0,000<0,05$ & Valid \\
\hline Pernyataan 3 & 0,539 & $0,000<0,05$ & Valid \\
\hline Pernyataan 4 & 0,733 & $0,000<0,05$ & Valid \\
\hline Pernyataan 5 & 0,635 & $0,000<0,05$ & Valid \\
\hline Pernyataan 6 & 0,498 & $0,000<0,05$ & Valid \\
\hline Pernyataan 7 & 0,539 & $0,000<0,05$ & Valid \\
\hline Pernyataan 8 & 0,733 & $0,000<0,05$ & Valid \\
\hline Pernyataan 9 & 0,635 & $0,000<0,05$ & Valid \\
\hline Pernyataan 10 & 0,586 & $0,000<0,05$ & Valid \\
\hline
\end{tabular}

Sumber : Hasil SPSS 20.0 (2017)

Dari kedua tabel diatas dapat ditarik kesimpulan bahwa setiap item pernyataan di masing-masing variabel lulus dari pengujian validitas.

\section{Reliabilitas}

Reliability (reliabilitas) berarti adanya ketepatan/keajekan/konsisten data yang di dapat dari waktu ke waktu. Reliabilitas berkenaan dengan tingkat keandalan suatu instrument penelitian itu. Jika nilai koefisien reliabilitas (Cronbach's Alpha) > 0,6. Maka instrument memiliki reliabilitas yang baik atau dengan kata lain instrument adalah reliabel atau terpercaya.

Tabel 6Hasil Pengujian Reliabilitas

\begin{tabular}{ccc}
\hline Variabel & $\begin{array}{c}\text { Nilai } \\
\text { Reliability }\end{array}$ & Kesimpulan \\
\hline Variabel $X_{1}$ & $0,772>$ & Reliabel \\
& 0,6 & \\
\hline Variabel Y & $0,809>0,6$ & Reliabel
\end{tabular}

Sumber : Hasil SPSS 20.0 (2017)

Dilihat dari tabel diatas dapat disimpulkan bahwa pernyataan kuesioner dalam penelitian ini lulus dari pengujian reliabilitas.

\section{Teknik Analisis Data}

Pada bagian ini penulis akan menganalisa dan menjelaskan data-data yang penulis miliki untuk menjawab hipotesis yang penulis kemukakan. Berikut ini adalah analisa data dan pengujian-pengujian data yang penulis gunakan untuk menjawab hipotesis.

\section{Uji Asumsi Klasik}

Pengujian klasik secara sederhana bertujuan untuk mengidentifikasi apakah model yang baik atau tidak. Ada beberapa pengujian asumsi klasik yang penulis gunakan dalam penelitian ini, yaitu:

\section{Uji Normalitas Data}

Uji normalitas data bertujuan untuk mengetahui apakah distribusi sebuah data mengikuti atau mendekati distribusi normal, uji normalitas ini memiliki dua cara untuk 
mengikuti apakah distribusi data normal atau tidak yaitu melalui pendekatan histogram dan pendekatan grafik.

Kriteria Pengujian :

a) Data berdistribusi normal apabila distribusi data tersebut miring ke atas atau melenceng kekanan.

b) Data tidak berdistribusi normal apabila distribusi data tersebut ke kiri atau ke kanan

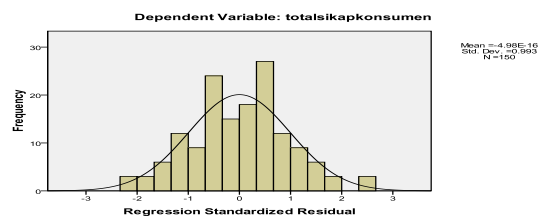

Gambar1Histrogram

Berdasarkan kriteria pengujian distribusi normal, maka data di atas dapat dikatakan telah berdistribusi normal karena distribusi data tersebut tidak miring ke kiri atau ke kanan.

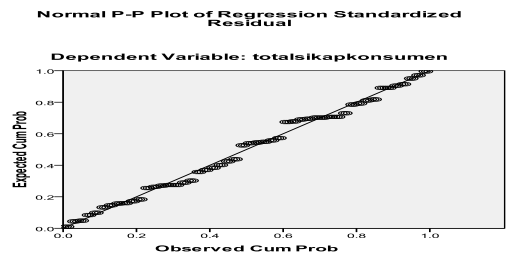

\section{Gambar 2Uji Normalitas $P$ - $P$ plot of Regression}

Gambar 2 Uji Normalitas Data di atas mengidentifikasikan bahwa model regresi telah memenuhi asumsi yang telah dikemukakan sebelumnya, sehingga data model regresi penelitian ini cenderung normal.

\section{c) Uji Multikolinearitas}

Multikolinearitas digunakan untuk menguji apakah pada model regresi ditemukan adanya korelasiyang kuat antar variabel indevenden, cara yang digunakan untuk menilainya adalah dengan melihat nilai faktor inflasi varian (variance inflasi faktor/VIF), yang tidak melebihi 4 atau 5 .
Tabel 7Multikolinearitas

\section{Coefficients $^{\mathrm{a}}$}

\begin{tabular}{lll}
\hline Model & \multicolumn{2}{l}{ Collinearity Statistics } \\
\cline { 2 - 3 } & Tolerance $\quad$ VIF \\
\hline & & \\
\cline { 2 - 2 } Totaliklan & .179 & 5.588 \\
\hline
\end{tabular}

a. Dependent Variable: totalsikapkonsumen

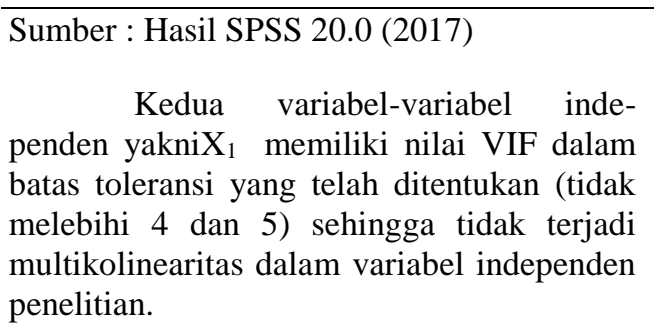

\section{Uji Heterokedasitas}

Uji ini memiliki tujuan untuk mengetahui apakah model regresi terjadi ketidak samaan varian dari residual pengamatan yang lainnya tetap, maka disebut homoskedastisitas sebaliknya jika varian berbeda maka disebut heteroskedastisitas.Ada tidaknya heteroskedastisitas dapat diketahui dari melihat grafik scatterplot antar nilai predikasi variabel independen dengan nilai residualnya. Dasar analisis yang dapat digunakan untuk menentukan heteroskedastisitas antara lain:

a) Jika ada pola tertentu seperti titiktitik yang membentuk pola tertentu yang teratur (bergelombang melebar kemudian menyempit) maka telah terjadi heteroskedastisitas.

b) Jika tidak ada pola yang jelas seperti titik menyebar di atasan bawah angka 0 pada sumbu $\mathrm{Y}$, maka tidak terjadi heteroskedastisitas. 


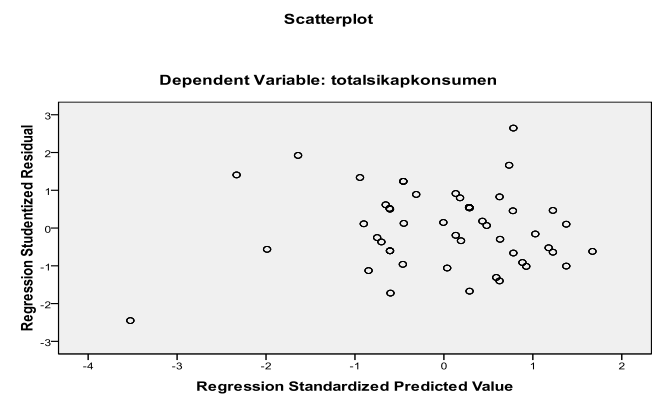

Gambar 3Uji Heteroskedastisitas

Gambar 3 Uji heteroskiditas diatas memperlihatkan titik-titik menyebar secara acak, tidak membentuk pola yang jelas atau teratur, serta tersebar baik diatas maupun dibawah angka 0 pada sumbu Y. Dengan demikian "tidak terjadi heterokedastisitas" pada model regresi.

\section{Regresi Linier Berganda}

Untuk mengetahui keeratan pengaruh terhadap keputusan pembelian, maka dapat digunakan regresi linier berganda. Persamaan regresi berganda dapat dilihat dari nilai koefisien B pada tabel berikut

\section{Tabel 1 Regresi Linear Berganda}

\begin{tabular}{|c|c|c|c|c|c|c|}
\hline \multicolumn{7}{|c|}{ Coefficients $^{\mathbf{a}}$} \\
\hline & \multirow{2}{*}{ Model } & \multicolumn{2}{|c|}{ Unstandardized Coefficients } & $\begin{array}{c}\text { Standardized } \\
\text { Coefficients }\end{array}$ & \multirow{2}{*}{$\mathrm{t}$} & \multirow{2}{*}{ Sig. } \\
\hline & & B & Std. Error & Beta & & \\
\hline \multirow[t]{2}{*}{1} & (Constant) & 6.155 & 1.465 & & 4.200 & .000 \\
\hline & otal Iklan & 212 & .054 & 291 & 3.918 & .000 \\
\hline
\end{tabular}

a. Dependent Variable: totalsikapkonsumen

Sumber : Hasil SPSS 20.0 (2017)

Berdasarkan perhitungan yang dilakukan menggunakan SPSS 20.0 diatas akan di dapat persamaan regresi linier berganda, model regresinya sebagai berikut:

$\mathrm{Y}=\mathrm{a}+\mathrm{b}_{1} \mathrm{X}_{1}+\varepsilon$

$Y=6,155+0,212 X_{1}+\varepsilon$

Persamaan regresi linier berganda diatas dapat diartikan sebagai berikut: (1) Konstanta (a) sebesar 6,155 artinya apabila terdapat variabel independen seperti iklan maka akan terjadi sikap konsumen pada produk sepeda motor yamaha adalah sebesar $6,2 \%$. (2). $\beta_{1}$ sebesar 0,212 artinya iklan berpengaruh positif terhadap sikap konsumen, dimana apabila iklan naik $1 \%$, maka sikap konsumen akan naik sebesar $21,2 \%$.

\section{Uji t (parsial)}

Uji statistik t pada dasarnya bertujuan untuk menunjukan seberapa jauh pengaruh satu variabel dependen. Kriteria pengambilan keputusan yaitu $\mathrm{H}_{0}$ diterima jika: $-t_{\text {hitung }}<-t_{\text {tabel }}$ atau $t_{\text {hitung }}<t_{\text {tabel }}$ sedangkan $\mathrm{H}_{0}$ ditolak jika: $-\mathrm{t}_{\text {hitung }}>-\mathrm{t}_{\text {tabel }}$ atau $\mathrm{t}_{\text {-hitung }}>\mathrm{t}_{\text {tabel. }}$. Untuk uji statistik $\mathrm{t}$, penulis menggunakan pengolahan data SPSS for windows versi 20.0, maka dapat diperoleh hasil uji t sebagai berikut: 
Prosiding Seminar Nasional Multidisiplin Ilmu Universitas Asahan 2018

Tema : "Strategi Membangun Penelitian Terapan yang Bersinergi dengan Dunia Industri, Pertanian dan Pendidikan dalam Meningkatkan Daya Saing Global"

06 November 2018, Kisaran

Tabel 9. Uji t (Parsial)

\section{Coefficients $^{a}$}

\begin{tabular}{|c|c|c|c|c|c|c|}
\hline & \multirow[b]{2}{*}{ Model } & \multicolumn{2}{|c|}{$\begin{array}{c}\text { Unstandardized } \\
\text { Coefficients }\end{array}$} & \multirow{2}{*}{$\begin{array}{c}\text { Standardized } \\
\text { Coefficients } \\
\text { Beta }\end{array}$} & \multirow[b]{2}{*}{$\mathrm{t}$} & \multirow[b]{2}{*}{ Sig } \\
\hline & & B & Std. Error & & & \\
\hline \multirow[t]{2}{*}{1} & (Constant) & 6.155 & 1.465 & & 4.200 & .000 \\
\hline & totaliklan & .212 & .054 & .291 & 3.918 & .000 \\
\hline
\end{tabular}

a. Dependent Variable: totalsikapkonsumen

\section{Sumber : Hasil SPSS 20.0 (2017)}

\section{Pengaruh Iklan (X1) terhadap Sikap Konsumen (Y)}

Uji $\mathrm{t}$ digunakan untuk mengetahui apakah strategi berpengaruh secara individual (parsial) mempunyai hubungan yang signifikan atau tidak terhadap loyalitas konsumen. Untuk kriteria uji t dilakukan pada tingkat $\alpha=0.05$ dengan nilai t untuk $\mathrm{n}$ $=150-2=148$ adalah $1,976 . \mathrm{T}_{\text {hitung }}=3,918$ dan $\mathrm{t}_{\text {tabel }}=1,976$.

\section{Tabel 10Uji F (Simultan)}

\section{Uji F (Simultan)}

Uji statistik $\mathrm{F}$ dilakukan untuk menguji apakah variabel bebas (X) secara simultan mempunyai hubungan yang signifikan atau tidak terhadap variabel terikat (Y).Berdasarkan hasil pengolahan data dengan program SPSS versi 20.0, maka diperoleh hasil sebagai berikut :

\begin{tabular}{cccccc}
\hline \multicolumn{7}{c}{ ANOVA $^{\mathbf{b}}$} & & \\
\hline Model & Sum of Squares & df & Mean Square & F & Sig. \\
\hline 1 Regression & 2886.235 & 2 & 1443.117 & 433.710 & $.000^{\text {a }}$ \\
\hline Residual & 489.125 & 147 & 3.327 & & \\
\hline Total & 3375.360 & 149 & & & \\
\end{tabular}

a. Predictors: (Constant), totaliklan

b. Dependent Variable: totalsikapkonsumen

Sumber : Hasil SPSS 20.0 (2017)

Dari uji ANOVA (Analysis of Variance) pada tabel diatas dapat dilihat bahwa nilai $F_{\text {hitung }}$ sebesar 433,710 dengan tingkat signifikan sebesar 0.000. Sedangkan
$F_{\text {tabel }}$ diketahui sebesar 3,058. Berdasarkan hasil tersebut dapat diketahui bahwa $F_{\text {hitung }}>F_{\text {tabel }} 433,710>3,058$ artinya $H_{0}$ ditolak. 


\section{Koefisien Determinasi $\left(\mathbf{R}^{2}\right)$}

Identifikasi koefisien determinasi ditunjukkan untuk mengetahui seberapa besar kemampuan model dalam menerangkan variabel terikat.Jika koefisien determinasi $\left(\mathrm{R}^{2}\right)$ semakin besar atau mendekati 1, maka dapat dikatakan bahwa kemampuan variabel (X) adalah besar terhadap variabel terikat (Y).Hal ini berarti model yang digunakan semakin kuat untuk menerangkan pengaruh variabel bebas yang diteliti dengan variabel terikat. Sebaliknya, jika koefisien determinasi $\left(\mathrm{R}^{2}\right)$ semakin kecil atau mendekati 0 , maka dapat dikatakan bahwa kemampuan variabel bebas(X) terhadap variabel terikat $(\mathrm{Y})$ semakin kecil

\section{Tabel 12Koefisien Determinasi}

\section{Model Summary}

\begin{tabular}{|c|c|c|c|c|c|}
\hline Model & $\mathrm{R}$ & R Square & $\begin{array}{l}\text { Adjusted } \\
\text { Square }\end{array}$ & ${ }^{\mathrm{R}}$ Std. Error of the Estimate & $\begin{array}{l}\text { Durbin- } \\
\text { Watson }\end{array}$ \\
\hline 1 & $.925^{\mathrm{a}}$ & .855 & .853 & 1.82411 & 1.772 \\
\hline \multicolumn{6}{|c|}{ a. Predictors: (Constant), totaliklan } \\
\hline
\end{tabular}

Sumber : Hasil SPSS 20.0 (2017)

Dari hasil uji R Square dapat dilihat bahwa nilainya dalah 0,855 dan hal ini menyatakan bahwa variabel iklan sebesar $85,5 \%$ untuk mempengaruhi variabel sikap konsumen.

\section{KESIMPULAN}

Berdasarkan hasil penelitian adanya pengaruh positif dan signifikan pada iklan

\section{DAFTAR PUSTAKA}

Amstrong, Gery Dan Philip Kotler.2012. Prinsip-Prinsip Pemasaran .Edisi 16.Jakarta :Erlangga

Mega Usvitas, Pengaruh Iklan Dan Sikap Konsumen Terhadap Keputusan Pembelian (Cream Wajah Ponds Pada Mahasiswa Sekolah Tinggi Ilmu Ekonomi Yayasan Pendidikan Pasaman). E-Journal Apresiasi Ekonomi Volume.1 No.1 Januari 2013

Mowen, Jhon C Dan M.Minor. 2002. Prilaku Konsumen. Alih Bahasa: Dwi Kartini Yahya. Jilid 2. Erlangga Jakarta terhadap sikap konsumen pada produk sepeda motor yamaha. Artinya semakin baik perusahaan dalam melakukan periklanan kepada konsumen, maka tingkat pembelian akan produk sepeda motor yamaha akan semakin meningkat dan semakin baik.

Kotler, P. 2006. Manajemen Pemasaran. Edisi Millennium. PT. Prenhalindo Jakarta

Kotler Dan Koller. 2009. Manajemen Pemasaran. Jilit Pertama, Edisi Kesebelas. PT. Indek Kelompok Gramedia: Jakarta

Peter, Paul \&Jerry C Olson.2005.Consumer Behavior. Alih Bahasa: Damos Sihombing. Jakarta: Erlangga

Rangkuti, Freddy.2009. Measuring Customer Satisfaction, Jakarta: Gramedia Simamora, Bilson. 2002. Riset Pemasaran. Jakarta: PT Gramedia Pustaka Utama

Sigit Raharja, 2011. Analisis Pengaruh Efektifitas Iklan Terhadap Sikap Konsumen Dan Keyakinan 
Prosiding Seminar Nasional Multidisiplin Ilmu Universitas Asahan 2018

Tema : "Strategi Membangun Penelitian Terapan yang Bersinergi dengan Dunia Industri, Pertanian dan Pendidikan dalam Meningkatkan Daya Saing Global"

06 November 2018, Kisaran

Konsumen Pada Niat Beli Rokok Star Mild Di Surabaya

Sugiono,(2012). Metode Penelitian Bisnis

Cetakan Ke 16. Alphabeta Bandung Ummas Sahibul Qolbi,Dkk. Pengaruh Iklan Terhadap Sikap Konsumen ( Survey Pada
Pengunjung Yang Pernah Bermain Game Pro Evolution On Soccer Di Flox Capital Of Entertainment Kec Belimbing Kota Malang). Jurnal Administarsi Bisnis (Jab)Vol. 10 No. 1 Mei 2014 